\title{
MESTO KOT EKOSISTEM
}

\section{dr. Metka Špes}

Oddelek za geografijo, Filozofska fakulteta Univerze v Ljubljani

Aškerčeva 2, SI- I000 Ljubljana

e-mail: metka.spes@ff.uni-lj.si

Izvirni znanstveni članek

COBISS 1.01

\section{Izvleček}

Mesta lahko pri iskanju svoje poti v trajnost najdejo dobre strokovne podlage, razlage in vzore v razumevanju delovanja ekosistemov. Če mesto prepoznamo kot ekosistem z medsebojno povezanostjo in soodvisnostjo vseh njegovih sestavin, lažje definiramo tudi njegovo nosilno sposobnost in $\mathrm{z}$ razumevanjem njegovega metabolizma razložimo še vzroke in posledice negativnih učinkov človekovega delovanja. Z razumevanjem mesta kot odprtega ekosistema prepoznamo tudi njegovo delovanje, vlogo in vplive na različnih ravneh. V prispevku so predstavljeni tudi pogoji in izzivi, ki se jim bodo morala približati mesta na poti k trajnosti.

Ključne besede: mesto, urbani ekosistem, trajnostni razvoj

\section{A TOWN AS AN ECOSYSTEM}

\begin{abstract}
In the search for their way towards sustainability towns can find good expert bases, explanations and models in the comprehension of ecosystems functioning. If a town is regarded as an ecosystem in which all its components are interconnected and interdependent, it is easier to define its carrying capacity; and to understand its metabolism means that the causes and results of negative impacts of human activities can further be explained. When a town is understood as an open ecosystem, its functioning, role and impacts on different levels can also be identified. Presented are also the conditions and challenges which will have to be faced by the towns on their way to sustainability.
\end{abstract}

Key words: town, urban ecosystem, sustainable development 


\section{UVOD}

Mesto kot zapleten prostorski pojav lahko obravnavamo tudi kot močno antropogeno preoblikovan ekosistem ali kot ekosistem z dodatnimi energetskimi vnosi, ki so vse večji potrošnik dobrin in okoljskih (ekoloških) storitev. Razumevanje urbanega ekosistema kot funkcionalne celote, $\mathrm{v}$ kateri so povezane nežive in žive sestavine, kjer krožijo snovi in energija, ponuja dobro strokovno podlago tudi za načrtovanje njegovega trajnostnega razvoja, kjer je potrebno vedno znova iskati ravnovesje med vsemi njegovimi sestavinami. Pogoj za doseganje trajnosti pa je v tem, da je razvoj skladen z nosilno zmogljivostjo urbanega ekosistema in da temelji na zahtevi po vzdrževanju ekosistemske stabilnosti. Dopušča torej spremembe, človekove vplive oziroma razvoj, ki pa ne smejo presegati zmogljivosti ekosistema. Trajnost v razvoju mest oziroma urbanih ekosistemov pomeni vzdrževanje dinamičnega ravnovesja, ki zagotavlja prebivalcem kvalitetno življenje, razvoj pa upošteva osnovne ekosistemske mehanizme. Za mesta, ki se razlikujejo po številu prebivalcev, površini, gospodarskih, ekoloških in drugih značilnosti, ni mogoče uporabiti splošnega koncepta trajnostnega razvoja, vedno ga je potrebno prilagajati naravnemu potencialu in lokalnim mestnim razmeram. Obstaja pa nekaj univerzalnih 'mehkih' priporočil o tem, kako bi mesta že z manjšimi posegi in finančnimi vložki, predvsem pa s tem, da bi prebivalci spremenili svoje vrednote in vzorce obnašanja, že dosegla pomemben premik v trajnost.

\section{ZAKAJ PRI NAČRTOVANJU TRAJNOSTNEGA RAZVOJA POTREBUJEMO EKOSISTEMSKI POGLED NA MESTO?}

Pri preučevanju mest ter iskanju njihovih možnosti in priložnosti za trajnostni razvoj izkazuje ekosistemski pristop veliko prednosti v primerjavi s specialističnim, sektorskim pogledom na zapleten in kompleksen urbani sistem. Omogoča nam razumevanje vzrokov za različno kvaliteto življenjskega okolja, predvsem pa razlago učinkov posrednih in neposrednih vplivov človekovih dejavnosti na okolje ali na posamezne pokrajinotvorne sestavine, tako znotraj mest kot v njihovem zaledju ali širše. Trajnostni urbani razvoj izhaja iz ekosistemskega razumevanja mesta, kjer je potrebno vedno znova iskati ravnovesje med vsemi elementi urbanega življenja pa tudi med vnosi in iznosi. Bistvo trajnostnega razvoja urbanega ekosistema pomeni tudi njegovo sposobnost, da prenese spremembe, ki dolgoročno prinašajo socialni, gospodarski in tehnološki razvoj. Trajnost pomeni tudi nadaljevanje kvalitetnega in z nosilnostjo ekosistema usklajenega razvoja, ki pa ni končni cilj, ampak je uravnotežen in prilagodljiv evolucijski proces iskanja ravnovesja med materialnim blagostanjem, socialno varnostjo in zdravim okoljem. V preteklosti je bilo pri načrtovanju razvoja mest največ napak narejenih prav zaradi pomanjkanja kompleksnega razumevanja urbanih sistemov, kjer je kvaliteta življenja, socialna blaginja odvisna tako od gospodarskega razvoja kot od reševanja okoljskih problemov in stanja naravnih sestavin ekosistema. Po mnenju Pluta (2007) sodobne, trajnostno zasnovane definicije mest in mestnega okolja poudarjajo neobhodnost trajne prilagoditve mestnega razvoja zmogljivostim ekosistemov.

Če mesto prepoznavamo kot ekosistem, postavimo v ospredje tudi analize snovnoenergetskih tokov (mesto kot odprt sistem) in njegovih vplivov na mesto in okolico, razmerja 
obremenjevanja okolja do zmogljivosti okolja, problematike t.i. ponorov, obravnave naravnega kapitala mesta itd. (Plut 2006). Okoljsko obremenjevanje mest lahko razumemo tudi kot posledico prevelikega števila in obsega energetskih in materialnih vnosov, ki se ne morejo vgraditi v naravni krogotok. Pri obravnavi mesta kot sistema njegovih naravnih, antropogeno preoblikovanih in družbenih sestavin ter njihove medsebojne mrežne povezanosti, soodvisnosti in součinkovanja, lažje prepoznamo tudi njegove nosilne sposobnosti oziroma ranljivost urbanega ekosistema. Upoštevanje slednjega bi moralo biti temelj bodočega razvoja vsakega mesta in njihovega približevanja trajnosti. Pri mestu kot ekosistemu sledimo snovnoenergetskim vnosom, energetskim pretvorbam, pretokom, iznosom, kjer se ob zmanjšani uravnoteženosti povečujejo količine odpadkov v vseh agregatnih stanjih. S tem se znižuje kvaliteta urbanega življenja ter povečuje obseg in intenzivnost vplivov na mestno zaledje. Pomembno je torej nenehno iskanje ravnotežja med obremenjevanjem okolja in njegovo zmogljivostjo oziroma nosilnostjo. Ekosistemski pristop zahteva torej izrazito holističen pogled na mesto. Ko poudarjamo pomen razumevanja součinkovanja vseh sestavin urbanega ekosistema, mesto prepoznamo tudi kot sinergijsko tvorbo (če poznamo delovanje posameznih sestavin, ni nujno, da razumemo delovanje ekosistema kot celote).

Pri ekosistemskem pogledu gre torej za razumevanje mesta kot sistema, za katerega je značilno:

- neposredna povezanost, soodvisnost in ustvarjanje ravnovesja med njegovimi abiotskimi in biotskimi sestavinami;

- snovno-energetski pretok;

- pretok energije in njeno preoblikovanje na različnih trofičnih nivojih;

- da je dinamična združba proizvajalcev, uporabnikov in razgrajevalcev.

Že desetletja pred uveljavitvijo paradigme o trajnostnem razvoju so nastajale študije in strokovna razmišljanja o tem, da je potrebno mesta obravnavati kot sisteme, kjer prihaja do součinkovanja njegovih živih in neživih sestavin. Za prva, kjer se poudarja ekološki pogled na mesta, štejemo dela iz 30. let 20. st., ki so nastajala v ZDA, in katerih avtorji so bili še močno pod vplivom Darwinove teorije o boju za preživetje, ko so mestne prostorske strukture razlagali z zakonitostmi ekoloških procesov v naravi. Kljub nekritičnemu prenašanju naravnih zakonitosti na razvoj in delovanje družbe in mest, je njihova prednost v priznavanju, da je človek del narave in da tudi zanj veljajo naravne zakonitosti, da je torej tudi mesto kot antropogeno najbolj preoblikovan ekosistem tudi odvisen od naravnih procesov, oziroma, da je mogoče njegovo delovanje primerjati z živim organizmom, kar so pri kasnejših študijah večkrat spregledali.

Berryja (1974) se najpogosteje omenja kot utemeljitelja kompleksnega - ekosistemskega pogleda na preučevanje mesta, kjer so enakovredno obravnavane tako naravne kot družbene sestavine. Njegova teoretska izhodišča je s kompleksno oceno kakovosti okolja in življenja v Hongkongu nadgradil Boyden, ki je v študiji, predstavljeni leta 1977, primerjal stanje okolja in njegovih naravnih sestavin oziroma urbanega ekosistema z življenjem ljudi, predvsem njihove kvalitete bivanja, standarda in zdravja(Boyden 1977). Na podlagi pozitivnih rezultatov teh raziskav je skupina Boydenovih sodelavcev opravila še več vzorčnih preučevanj mest. V luči razlage ekosistemskega pristopa pri preučevanju mest je zanimivo še Havlickovo 
priporočilo (Havlick 1974; Douglas 1983), da je mesto potrebno obravnavati kot organizem, ki uporablja, zbira, pretvarja, prerazporeja energijo iz bližnjih ali oddaljenih območij. Od tod izhaja tudi razlaga 'mestnega metabolizma' in v nadaljevanju prepoznavanje njegove nosilne zmogljivosti, ki je po Havlickovem razumevanju urbanega ekosistema odvisna od lastne in 'uvožene' produktivnosti raznovrstnostih proizvajalcev. Nosilno sposobnost oziroma zmogljivost urbanega ekosistema in obenem tudi njegovo velikost pa naj bi definirali proizvajalci (primarni in sekundarni sektor), ker le-ti omogočajo obstoj in delovanje različnih skupin in (trofičnih) nivojev uporabnikov (terciarni in kvartarni sektor, bivanje). Vzgled jemlje iz vrstne piramide, kjer nosilno sposobnost ekosistema definirajo proizvajalci - teh je največ, od njih pa je odvisno preživetje ostalih organizmov na vrstni piramidi. Če pa organizme iz višjih trofičnih nivojev ne morejo več 'nositi' tisti iz spodnjih, morajo mesta posegati za dobrinami in energijo v ožje in širše zaledje, kar razume kot parazitizem (Havlick 1974). Obenem se s tem močno poveča še število energetskih pretvorb, ki ustvarjajo odpadek oziroma odpadno energijo in, če upoštevamo entropijski zakon, povečujejo nered. Energetski pretok in njeno pretvarjanje na različnih trofičnih nivojih proizvaja za delovanje mestnega organizma neuporabno-odpadlo energijo (entropija) in odpadke-več je pretvorb (predelave), več je neuporabne energije in odpadka.

Metodološki izziv predstavlja tudi odgovor na vprašanje, kako urbani ekosistem obravnavati in preučevati:

- mesto kot sistem;

- posamezne sestavine in nato iskati njihovo medsebojno povezanost;

- dominantne ali najpogostejše povezave med posameznimi deli ekosistema;

- urbani ekosistem kot povsem odprt sistem ali delno zaprt sistem;

- kako sprememba v enem delu ekosistema vpliva na drugi del oziroma druge ekosisteme (UNU/IAS Report 2003b).

Urbani ekosistemi so med vsemi najbolj odprti, označuje jih najmočnejši in najbolj raznovrsten snovno-energetski pretok. Poleg Sončeve energije, ki je prevladujoč energetski vnos v naravne ekosisteme, je v urbanih močno povečan vnos energije iz fosilnih goriv (latentna energija), ki se ne more vgraditi v biotski energetski krogotok. Odprtost urbanih ekosistemov povečuje še njihovo součinkovanje s sosednjimi, pa tudi bolj oddaljenimi ekosistemi. Zato spremembe v enem ekosistemu vplivajo na ostale, predvsem pa spremenjena raba tal ali povečevanje obsega in raznovrstnosti človekovih posegov vplivajo na delovanje, nepredvidljivost in povečano ranljivost ostalih. Na splošno lahko delovanje urbanih ekosistemov obravnavamo na treh nivojih: globalnem (preko porabe energije in naravnih virov), regionalnem (pritiski na sosednja ruralna območja z onesnaženjem, prostorskimi pritiski, rekreacijo, posegi v vodotoke) in lokalnem (mesta oblikujejo specifično notranje okolje). Breheny (1992) ugotavlja, da umeščenost mest na vseh treh ravneh ponuja mnogo priložnosti in izzivov, prav tako pa tudi nevarnosti in negotovosti. V odprtem sistemu čezmejnih tokov in globalizacije zunanji dejavniki močneje vplivajo tudi na stopnjo netrajnosti, lahko je celo uvožena ali izvožena.

Za razlago izzivov trajnostnemu razvoju urbanih ekosistemov se zato v praksi uporabljajo tri skupine raziskav oziroma tri ravni preučevanj, ki definirajo tudi prostorski obseg - velikost preučevanega ekosistema (prirejeno po UNU/IAS Report 2003a): 
1. raven: Mesto kot pogojno 'zaprt sistem'; obravnavamo ga v najožjem pomenu in predstavlja pretežno grajeni ekosistem s spremenjeno kakovostjo posameznih pokrajinotvornih sestavin, s specifično morfologijo, strukturo in funkcijo. Je življenjski prostor/habitat za mestno prebivalstvo, domače in prosto živeče živali ter zelene površine. Njegov obstoj in preživetje je vedno bolj odvisen od zunanje podpore (energija, voda, materialni vnosi). Za podrobnejša preučevanja lahko mesto nadalje delimo na optimalno homogene enote, večkrat se poudarjajo ekotopi (zelene površine, vrtički, mestni deli), katerih pomembna ekosistemska storitev je zagotavljanje kvalitetnega bivalnega okolja. Urbana ekologija pri tem vključuje še študije območij z različno stopnjo onesnaženosti/degradacije okolja, omogoča pa tudi socialnoekološke raziskave znotraj mesta oz. primerjave med različnimi mestnimi deli.

Slika 1: Primer prve ravni obravnave urbanega ekosistema in njegova členitev na različno onesnažena območja (glede na onesnaževanje in onesnaženost zraka, morfologijo in strukturo mesta ter mikroklimatske značilnosti)

Figure 1: A case of the first level of dealing with urban ecosystem and the division of the latter to differently polluted areas (with regard to the process and level of air pollution, the town morphology and structure and microclimate features)

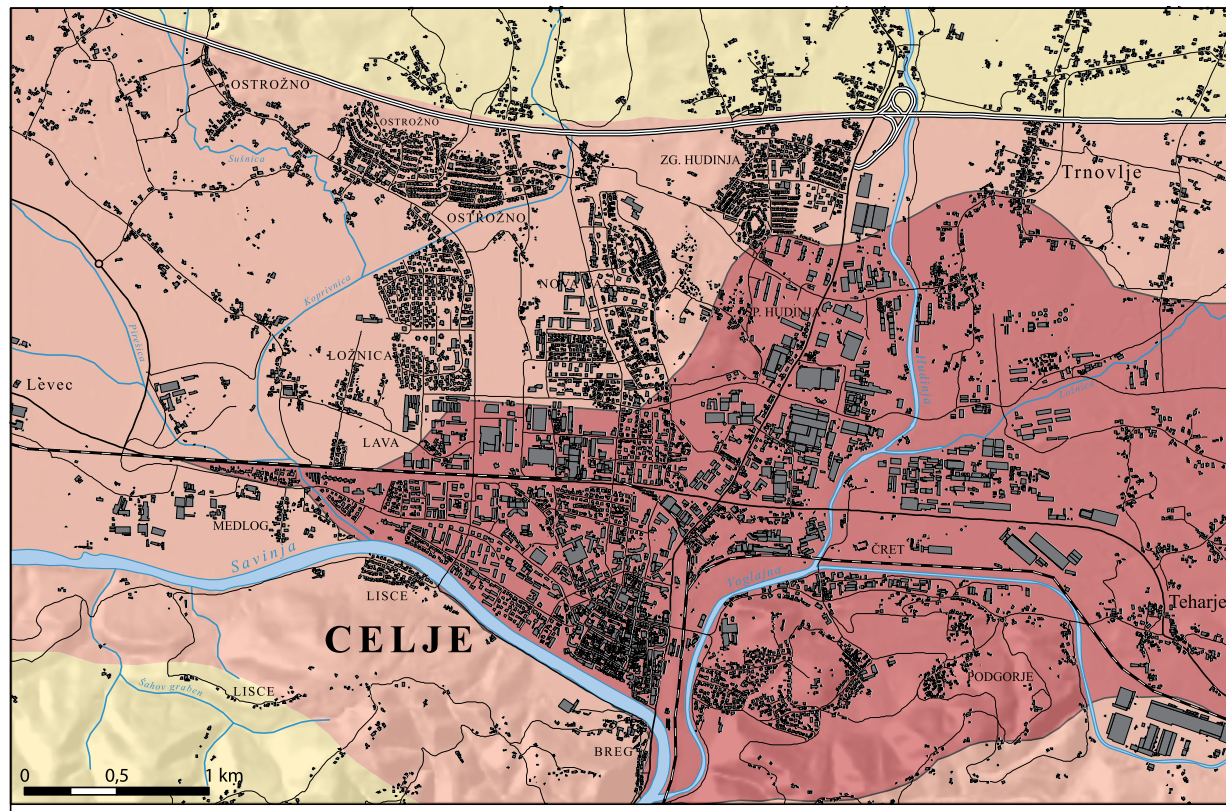

Območja po stopnji onesnaženosti okolja

okolje je zmerno onesnaženo

okolje je kritično onesnaženo

okolje je prekomerno onesnaženo

Kartografija: Andrej Herakovič, 2009

Vir/source: prirejeno po Špes 1998. 
2. raven: Mesto kot odprt ekosistem ob součinkovanju s sosednjimi: mesto je razumljeno kot organizem s svojim metabolizmom oziroma snovno-energetskimi vnosi in iznosi (energija, surovine, dobrine, hrana, voda, odpadki) ter pretvorbami na različnih nivojih. Tovrstne raziskave generirajo holistični pogled na mesto, $v$ ekosistem pa neposredno povezujejo še zaledje, ki mu nudi ekološke storitve (voda, rekreacija, proizvodnja biomase, tudi oskrba s hrano, vodo, materiali) oziroma območje, na katerega vplivajo urbane aktivnosti oziroma gonilne sile, ki podpirajo življenje v mestu. To je obenem območje vplivov mestnih emisij in odpadkov (imisijsko območje).

Sika 2: Ponazoritev druge ravni obravnave urbanega ekosistema - mesto kot odprti ekosistem, povezan z zaledjem, ki mu omogoča neposredne ekološke storitve in na katerega vpliva s svojim delovanjem

Figure 2: Illustration of the second level of dealing with urban ecosystem - a town as an open ecosystem connected with its hinterland which provides the direct ecological services and is influenced by the town's functioning

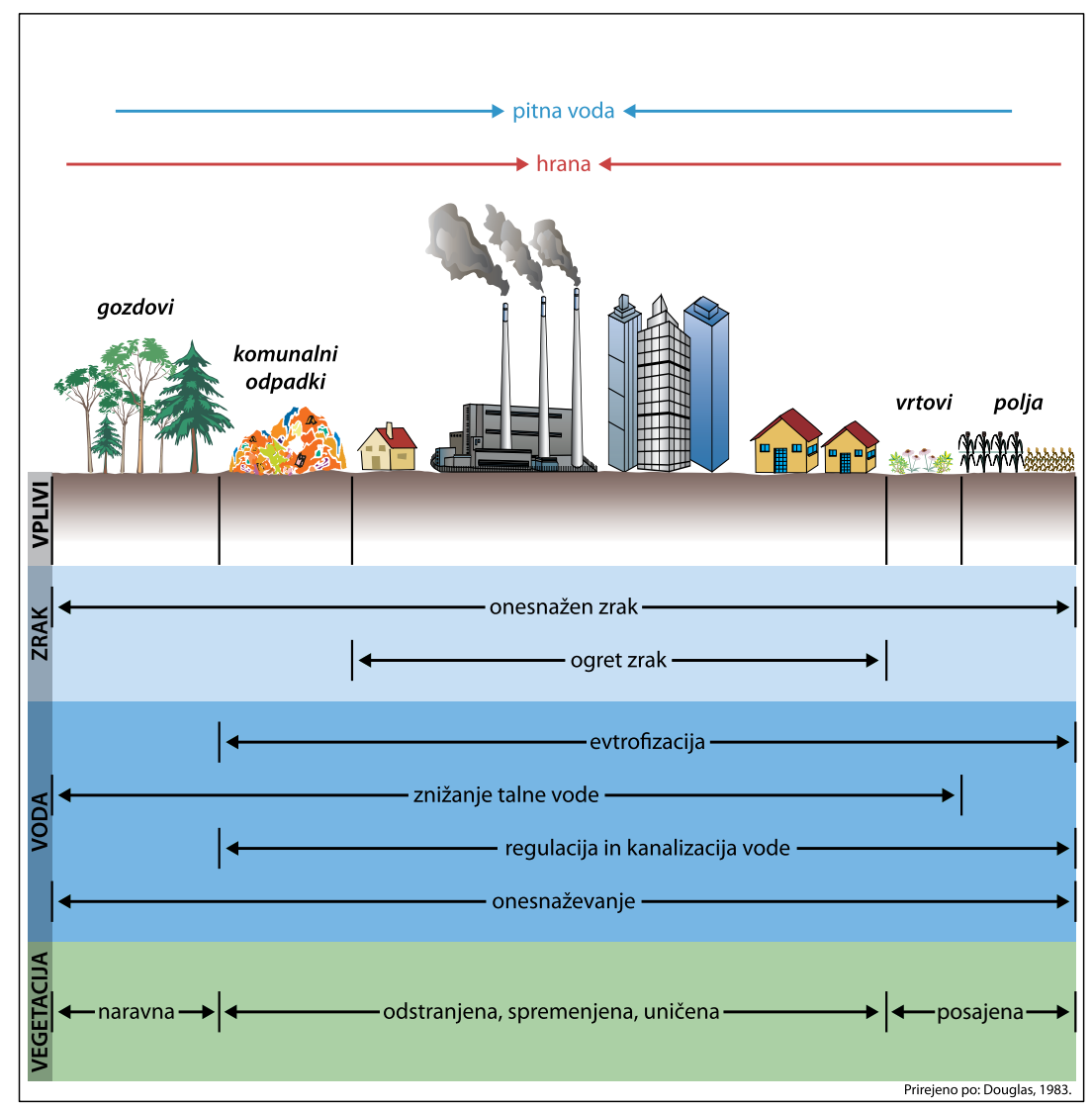


3. raven: Mesta kot del regionalnih in globalnih ekosistemov s poudarjeno povezanostjo in odvisnostjo mest s širšim regionalnim ali celo globalnim pretokom dobrin, uslug, znanja, ljudi. Globalna mesta vplivajo in izčrpavajo ekosisteme na velike razdalje. Ugotavljamo, da so mesta $\mathrm{v}$ razvitem svetu vedno manj samozadostna in da ustvarjajo vedno večji ekološki odtis.

Slika 3: Ponazoritev tretje ravni obravnave urbanega ekosistema - mesto kot del regionalnih in globalnih ekosistemov

Figure 3: Illustration of the third level of dealing with urban ecosystem - a town as part of regional and global ecosystems

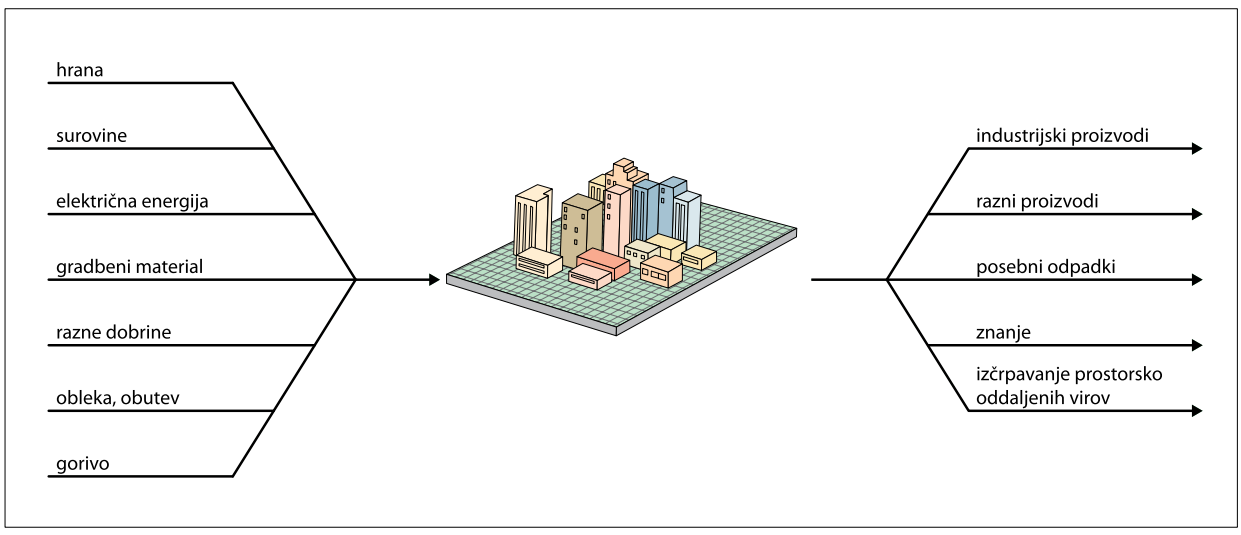

Vir/source: prirejeno po Vink 1983.

Aktualne študije urbanih ekosistemov temeljijo na:

- sistemskem pristopu, ki omogoča vrednotenje povezav med naravnim, okoljskim in socialnim sistemom, ponuja pa tudi osvetlitev hierarhije povezav med vsemi sestavinami, ki tvorijo ekosistem;

- biološkem pristopu, ki omogoča ugotavljanje pogojev za vzpostavljanje ravnovesja in predvsem naravnega potenciala, oziroma nosilne zmogljivosti urbanega ekosistema;

- prostorskih analizah z uporabo satelitskih in letalskih posnetkov ter GIS-ov;

- študiju mestnega metabolizma s snovno energetskim pretokom - ekološki odtis;

- socialnih analizah diferenciacije mesta ter prerazporejanja dobrin in znanja (UNU/IAS Report 2003b).

Med metodami za merjenje nosilne sposobnosti posameznih ekosistemov se od druge polovice 90. let tudi za mesta izračunava 'ekološki odtis', ki ponuja konceptualno orodje za razumevanje vplivov mest kot gonilne sile na ekosistemske spremembe. Temelji na informacijah o delovanju vseh treh sestavin oziroma trofičnih nivojev znotraj urbanega ekosistema: proizvajalcev, uporabnikov in razgrajevalcev. Upošteva pa obseg in količino proizvodnje biomase - na kopnem in v vodi (hrana in vlakna) in podatke o tem, koliko se $\mathrm{v}$ ta proces vrnejo in vgradijo 'odpadki', ki ostajajo od prebivalcev in njihovih dejavnosti. Ta metoda 
zagotavlja enostavne in razumljive odgovore na vprašanja, kdo in kaj proizvaja in uporablja, predvsem pa, za koliko raba naravnih virov (ekološki odtis) presega dejansko število tam živečega prebivalstva (Wackernagel in sod. 1996). Kritiki metodi očitajo, da temelji na zapletenih preračunavanjih večkrat težko dostopnih ali nenatančnih podatkov, ne nakazuje pa rešitev (UNU/IAS Report 2003b).

$\mathrm{S}$ holističnim pogledom na urbane ekosisteme ter $\mathrm{z}$ analizo snovno-energetskih pretokov lahko spremljamo tudi efektivnost rabe naravnih virov, stopnjo reciklaže oziroma vgradnjo odpadkov v metabolizem mest. Spremljanje urbanega metabolizma se namreč lahko uporablja tudi kot orodje za ugotavljanje okoljskih problemov (v povezavi z naraščanjem vnosov in gospodarjenjem z iznosi).

Ekosistemski pogled na mesto pa ima, kot vse druge sistemske teorije, tudi svoje pasti in slabosti, ki se kažejo predvsem v:

- nezadostnem poznavanju vseh pokrajinotvornih sestavin in njihovi nepredvidljivosti;

- vse sestavine niso enako preučene (na istem nivoji, časovno usklajeno);

- rezultati in razlage, ki temeljijo na sistemskem pristopu, so večkrat splošni in je zato otežena njihova interpretacija in aplikacija.

\section{IZZIVI, S KATERIMI SE SOOČAJO MESTA NA POTI K TRAJNOSTI}

V zadnjih desetletjih sledimo izrazito neugodnim trendom, ko se veliko mest, kljub deklarativnemu priseganju na trajnostni razvoj, od tega vedno bolj odmika. Premalo ali zelo redko znajo poiskati vzore svojega delovanja in razvoja v ekosistemskih mehanizmih ravnovesja. Vedno bolj se povečujejo razdalje med različnimi sferami človekovega delovanja, s tem se povečuje število in obseg vsakodnevnih migracij in uporaba prometnih sredstev, kar se ne odraža le v povečanem onesnaževanju okolja, ampak tudi v znižanju kvalitete življenja. Za potrebe urbanih dejavnosti se pogosto zmanjšuje obseg in kvaliteta zelenih površin in s tem biotska pestrost $\mathrm{v}$ mestu. Zaradi pozidanih in asfaltiranih površin se spreminja intenzivnost in smer pretoka energije (albedo) in vode (pospešeno izhlapevanje, zmanjšan in upočasnjen dotok v podtalnico, kanaliziran in reguliran pretok). S povečevanjem števila energetskih pretvorb se povečuje količina odpadkov, vnosi se povečujejo po obsegu in raznovrstnosti, vedno manj se vgrajujejo v biotski del ekosistema (ponor), zato postaja pretok vedno bolj enosmeren (nima naravne povratne zanke), z odpadkom na koncu.

Mesta se odmikajo od koncepta samozadostnosti in upoštevanja lastne nosilne sposobnosti tudi z naraščajočo globalizacijo. Povečuje se uporaba dobrin, katerih proizvajalci so vedno bolj oddaljeni, izkorišča energija, ki nastaja z izčrpavanjem in pretvarjanjem oddaljenih naravnih virov, velik del se je porabi že za prenos. Za oskrbo mest s hrano, surovinami in fosilnimi gorivi ter za shranjevanje, asimilacijo proizvedenih emisij so potrebne obsežne bioproduktivne gozdne, kmetijske in vodne površine (osnova za izračun ekološkega odtisa). Napake v preteklem razvoju mest so vidne na gospodarskem in socialnem področju, predvsem pa $\mathrm{v}$ poslabševanju kvalitete mestnega in širšega okolja in njegovih sestavin. Zato vedno bolj naraščajo zahteve in se povečujejo potrebe po vzpostavitvi novih vrednot in mehanizmov 
pri upravljanju mest. Vzore bo potrebno poiskati tudi v delovanju naravnih ekosistemov, ki so sposobni vzdrževati ravnovesje in se prilagajati spremembam ter zagotavljati preživetje. S tem bi omogočili tudi višjo kakovost urbanega življenja ter se izognili parazitizmu do ožjega in širšega zaledja.

Ali imajo mesta alternativo trajnostnemu razvoju?

Če mesta pri svojem razvoju ne bodo upoštevala osnovnih načel trajnosti, bodo začela najprej izgubljati na privlačnosti, demografsko bodo stagnirala ali celo nazadovala, izgubljala bodo delovna mesta, nadaljeval se bo neuravnotežen pretok energije in snovi (s povečevanjem okoljskih bremen), gospodarske in uslužnostne dejavnosti se bodo selile v privlačnejša in bolj stimulativna okolja, stopnjevala se bo neuravnotežena socialna varnost (Nijkamp in Perrels 1994). Negativni okoljski učinki so praviloma najbolj jasni signali netrajnosti. Njihovi vzroki pa so lahko zelo raznovrstni, od prekomerne rabe energije, neustreznih tehnologij, do neracionalne rabe prostora in slabe okoljske politike. Kažejo se predvsem v onesnaženosti zraka, voda, prsti, v hrupnem obremenjevanju, kakor tudi v pomanjkanju občutka varnosti in vizualni degradaciji. Posredno se posledice kažejo še v znižani ceni mestnega prostora in stanovanj, preseljevanju v druga mesta ali suburbana območja. Ob tem se zastavlja tudi vprašanje, ali lahko razloge za prostorsko širjenje urbanih ekosistemov z razpršeno suburbanizacijo iščemo predvsem ali tudi v netrajnosti dosedanjega razvoja mest?

Poročilo OECD (Environmental policies 1990) navaja še, da je trajnostno mestno okolje tisto, ki se razvija in raste $\mathrm{v}$ harmoniji s produktivno zmogljivostjo lokalnih, nacionalnih in globalnih ekosistemov. Mesto se torej ne more navznoter razvijati sonaravno, navzven (v okolico) pa 'izvažati’ visoko entropijo in emisijsko obremenjevanje. Trajnostni mestni razvoj je tisti, ki prinaša izboljšanje gospodarskega, socialnega in okoljskega blagostanja brez lokalnega in/ali globalnega izčrpavanja okoljskega kapitala.

Poleg 'trde' zahteve in potrebe po prepoznavanju nosilne sposobnosti urbanega ekosistema bodo morala mesta pri svojem doseganju ali vsaj približevanju k trajnosti spremeniti mnoge vzorce obnašanja in razvojne načrte, predvsem pa spremeniti vrednostne kazalce kakovostnega urbanega življenja. Aktualna razmišljanja strokovnjakov vidijo trajnostni razvoj mest tudi v njihovi optimalni samozadostnosti in postopnem zmanjševanju odvisnosti od produkcije v drugih okoljih. Girardet (2008) ugotavlja, da morajo trajnostna mesta težiti k samooskrbi, predvsem pa se čim bolj približati delovanju naravnih ekosistemov, z vzpostavitvijo t.i. krožnega metabolizma, ki ne pozna odpadka in onesnaževanja. Odpadki se morajo, kot končni produkt delovanja različnih sestavin ekosistema, optimalno absorbirati nazaj v lokalno okolje. To pa pomeni izrazit odmik od obstoječih linearnih razvojnih modelov.

Ob iskanju priporočil in pogojev za trajnostni razvoj urbanih ekosistemov, je strokovno najbolj zahteven izbor in priprava univerzalnih in za vsa mesta uporabnih kazalnikov za merjenje njihove trajnosti. Mesta se namreč med seboj razlikujejo po velikosti, naravno-geografskih značilnostih, genezi, morfologiji, funkciji, notranji strukturi, po gospodarskih, socialnih kazalnikih itd. Različne oblike urbanega razvoja pogojujejo tudi zelo različne trajnostno zasnovane strategije razvoja in spremembe v obstoječih mestnih površinah, prilagojene lokalnim mestnim razmeram. 
V priporočilih urbanih ekologov iz začetka prejšnjega desetletja najdemo nekaj osnovnih zahtev za uravnotežen razvoj urbanih ekosistemov (Nijkamp in Perrels 1994):

- zmanjšanje porabe prostora;

- zmanjšanje mobilnosti s krajšanjem razdalj med posameznimi sferami človekovih dejavnosti in posledično omejen urbani osebni transport;

- razširjanje in pospeševanje novih informacijskih tehnologij;

- zmanjšanje količine odpadkov in smotrno gospodarjenje z njimi;

- zmanjšanje porabe energije.

Kasneje so se ta priporočila, vzporedno z razvojem novih znanj in orodij, dopolnjevala, konkretizirala, predvsem pa so se jasneje definirale poti za njihovo doseganje. Še vedno je poudarjena zahteva po sprotnem prepoznavanju nosilne zmogljivosti urbanega ekosistema. Med univerzalnimi predlogi za hitrejše približevanje trajnosti in ekosistemskemu ravnovesju izstopajo predvsem priporočila po (povzeto in prirejeno po Ecotopedia 2008; avtorji: Gehl, Southworth, Girardet, Wackernagel in Burdet):

\section{a) Kompaktnost oziroma strnjenost mesta}

Mesta svojega razvoja ne bi smela povezovati z nenehnim prostorskim širjenjem oziroma $\mathrm{z}$ rastjo. Ohranjanje ekosistemskega ravnovesja je namreč nezdružljivo z nenehno rastjo. Odvisnost od rasti je eden izmed največjih ekosistemskih nesmislov in lahko resno ogroža nosilno zmogljivost. V naravnih ekosistemih dokazano ni soodvisnosti med opravljanjem funkcije in stopnjo rasti. $Z$ omejevanjem prostorskega širjenja mest bi se izognili tudi neracionalni rabi urbanega prostora, energije, vode itd. Mesta bi morala težiti k mešani rabi in čim manjšem oddaljevanju različnih sfer človekovega delovanja. Poraba dragocenega urbanega prostora je lahko večkratna (npr. gradnja podzemnih garaž). Nekatere raziskave v Sloveniji kažejo, da porabimo 4,5-krat več urbanega prostora za vsakega prebivalca kot npr. na Danskem ali Nizozemskem, ker se potratno in neracionalno uporabljajo zemljišča za gradnjo hiš, podjetij, trgovskih objektov. Zato je tudi v neposredni bližini mestnih naselij od 15 do 20 \% površin neustrezno izrabljenih (Dekleva 1998; citirano po Plut 2006). Pogačnik (1999) sklepa, da bi lahko ob večji gostoti poselitve v Sloveniji na enaki površini stanovanjskih območij živela tretjina več prebivalcev. Tudi evropska komisija za okoljsko urbano politiko izpostavlja, da so sklenjena mesta energetsko najbolj primerna oblika bivanja, ker je poraba energije za promet najmanjša, obenem pa je največ možnosti za učinkovito organiziranje javnega prometa. Kompaktna mesta nudijo tudi večjo kakovost življenja, priporočajo pa tudi, da naj bi se bodoča urbana rast omejevala le znotraj obstoječih urbanih območij (Environmental policies 1990).

\section{b) Dobro organiziran promet, pri javnem prometu prevladujoča uporaba obnovljivih virov energije}

Mesta bi morala svoje delovanje organizirati tako, da bi se optimalno zmanjšala potreba po uporabi osebnih avtomobilov, stoječ promet pa iz dragocenih mestnih površin premakniti v podzemne garaže. Vzporedno je potrebno izboljšati kvaliteto, dostopnost in pogostnost javnega prometa, predvsem pa povečati dostopnost in varnost pešcem in kolesarjem, kar pa je v veliki meri odvisno od tega, če mesto zadosti že omenjeni kompaktnosti. 


\section{c) Vzpodbujanje gradnje energetsko varčnih in lokalnemu okolju prilagojenih zgradb}

Prinovogradnjahinadaptacijahstarejšihzgradbjepotrebnotežitikzagotavljanjuoptimalne energetske varčnosti, kjer je pomembno tudi, da graditelji uporabljajo lokalne in naravnim značilnostim prilagojene gradbene materiale in tehnike gradnje. To ne pomeni vračanje nazaj, ampak izkoriščanje znanja in dobrih izkušenj starejših graditeljev s prilagoditvijo sodobnim zahtevam po kakovostnem bivalnem okolju. Vedno bolj aktualna je potreba po tem, da se pri načrtovanju novih zgradb upoštevajo še napovedane klimatske spremembe (vgradnja energetsko potratnih klimatskih naprav je najslabši odgovor segrevanju ozračja). Drozg (1995) je pri svojem preučevanju morfologije slovenskih naselij našel veliko skladnost med tradicionalnim načinom gradnje in naravnogeografskimi značilnostmi posameznih slovenskih pokrajin, oziroma domiselne načine premagovanja 'naravnih neugodnosti' kot so veter, temperature, relief. V obmorskih naseljih npr. ozke ulice in gradbeni material omogočajo zadrževanje hladnejšega zraka v poletnih mesecih in varujejo hiše pozimi pred vdorom hladnih vetrov. Hiše izkoriščajo še temperaturne razlike v posameznih delih zgradbe za gibanje zraka in jih na tak način tudi prezračujejo. Naši predniki so pri oblikovanju svojih bivališč velika okna obračali na prisojno stran (kot rastline svoje cvetove in liste proti soncu), manjša pa na osojno. V mestih so veliko bolj zanimive razgibane fasade kot enolične zgradbe, ki v ničemer ne odražajo specifičnosti okolja.

\section{d) Prehod k obnovljivim virom energije}

Poleg že omenjenih priporočil po rabi obnovljivih virov energije v prometu in ogrevanju ali hlajenju stanovanjskih zgradb je za zagotavljanje trajnosti zelo pomembno, da se mestni razvoj načrtuje tako, da bo zagotovljena optimalna raba energije iz obnovljivih virov. To pomeni tudi korenit odmik od dosedanjega prevladujočega razvojnega modela, ki je v glavnem slonel na uporabi fosilnih energetskih virov.

\section{e) Ohranjanje ali celo širjenje kakovostnih zelenih površin in naravnih prezračevalnih koridorjev}

Pri zelenih površinah ne gre zgolj za javne površine, kot so parki, zelenice, športna in otroška igrišča, ampak tudi za zelene površine, ki imajo proizvodno funkcijo, npr. vrtovi, vrtički, mestni gozd itd. To so za urbani ekosistem pomembni ekotopi s povečano biotsko pestrostjo in ponekod pomembni celo za proizvodnjo hrane za lokalno prebivalstvo. Zelene površine ugodno vplivajo še na kakovost zraka (kisik), zmanjševanje hrupa in upočasnjen vodni krogotok (evapotranspiracija namesto evaporacije iz pozidanih površin). Na teh površinah se urbani ekosistem najbolj približa naravnemu snovno-energetskemu krogotoku. Poleg tega je vzdrževanje odprtih površin pomembno tudi za ohranjanje vetrnih koridorjev, naravno prezračevanje in učinke toplotnega otoka.

\section{f) Približevanje k naravnemu snovno-energetskemu krogotoku oziroma h krožnemu metabolizmu mesta}

Po vzgledu v delovanju naravnih ekosistemov, kjer se ‘odpadki' vgradijo v proizvodnjo biomase, naj bi tudi v urbanem ekosistemu uporabljali čim več biorazgradljivih snovi. Tako bi se $\mathrm{z}$ odmikom od dosedanjih linearnih procesov $\mathrm{v}$ urbanem ekosistemu, ki na koncu proizvajajo neuporabne odpadke $\mathrm{v}$ vseh treh agregatnih stanjih, začeli počasi približevati 
snovno-energetskemu krogotoku z zmanjšanimi količinami emisij. Danes se velike količine komunalnih odpadkov, ki so pretežno organski, odlagajo na odlagališča, iz katerih se ob gnitju sprošča tudi toplogredni metan. Primerneje je kompostiranje in odlaganje na kmetijske površine. Organske odpadke naj bi v optimalnih količinah proizvajalci (zelene rastline) ponovno vgradili v biomaso, ki nato mestu nudi ekološke storitve (biotska raznovrstnost, hrana, zelene površine). Pri dosedanjem linearnem človekovem delovanju pa se večina neobnovljivih naravnih virov uporabi kot surovina za proizvode, ki se na koncu zavržejo v obliki odpadka. Zato naraščajo količine odpadkov. Trajnostno ravnanje z odpadki bi pomenilo premik od linearnega načina razmišljanja $\mathrm{k}$ cikličnemu, zato bi se morali odpadki kot surovine vrniti na začetek snovnega toka - reciklirati. S stališča snovnih in energetskih bilanc ima preprečevanje, vnovična uporaba, predelava, reciklaža neprimerno boljši snovni izkoristek (Keuc 2005). V svetu se danes pojavljata dve strategiji ravnanja z odpadki: T.i. integralno gospodarjenje predvideva le okoli $40 \%$ reciklaže in s tem dopušča v veliki meri tudi ohranjanje dosedanjih vzorcev odnosa do odpadkov. Boljše, a v praksi težko dosegljivo, je priporočilo 'zero waste', po katerem se spremlja cel življenjski cikel proizvoda kot odpadka, ki vključuje reciklažo po načelu: dober odpadek je tisti, ki ga je mogoče reciklirati.

\section{g) Povečana samooskrba mesta}

Zmogljivost urbanega ekosistema in stopnjo njegove trajnosti se ocenjujejo tudi po tem, kolikšnemu deležu potreb in zahtev za življenje in delovanje vseh podsistemov zadošča njegov potencial, oziroma, kakšno stopnjo samooskrbe zagotavlja. Trajnostni urbani ekosistemi bi morali težiti k temu, da čim več snovno-energetskih vnosov, ki zadovoljujejo vsakodnevne potrebe meščanov (hrana, energija in ostalo), izhaja iz lokalnih in le pogojno iz regionalnih ali globalnih virov. Kot pomemben kazalec trajnosti mestnega razvoja se vse pogosteje uporabljajo informacije o pridelavi in uporabi lokalne hrane in drugih proizvodov kot antipod zelo razširjeni, snovno energetsko potratni in entropijski globalizaciji oskrbe.

\section{h) Usklajeno in uravnoteženo delovanje vseh podsistemov znotraj urbanega ekosistema}

Usklajeno delovanje vseh podsistemov (proizvodnja, bivanje, oskrba, promet, socialni, zdravstveni in izobraževalni) pomeni premišljeno načrtovanje, tako da z medsebojnim dopolnjevanjem ustvarjajo kakovostno življenjsko okolje v mestu in da med njimi ne prihaja do prostorskih konfliktov, težnje po dominaciji in drugih negativnih pojavov. Urbani ekosistem se mora razvijati in delovati holistično - kot optimalno homogena celota in ne kot seštevek različnih dejavnosti, ki se razvijajo sektorsko. Z usklajenim razvojem bodo enostavneje dosegljivi tudi predhodni cilji trajnosti (kompaktnost, dostopnost javnih institucij pešcem in kolesarjem in drugo) in s tem tudi glavni namen trajnostnega razvoja - da je mesto ljudem prijazno.

\section{SKLEP}

Ekosistemski pristop ima pri razumevanju mest za potrebe načrtovanja trajnostnega razvoja veliko primerjalnih prednosti pred preučevanjem posameznih sestavin ali dejavnosti 
urbanega sistema. Razumevanje mesta kot ekosistema nam namreč omogoča tudi iskanje ravnotežja med vsemi elementi urbanega življenja, pa tudi med vnosi in iznosi ali njihovo vrednotenje glede na nosilne zmožnosti mestnega okolja. Trajnostni razvoj, ki je v bistvu evolucijski proces nenehnega iskanja ravnotežja med nosilnostjo ekosistema in spremembami, ki dolgoročno prinašajo socialni, gospodarski in tehnološki razvoj, zahteva poznavanje in razumevanje vseh njegovih sestavin, predvsem pa njihove medsebojne mrežne povezanosti. Spremembe v posamezni sestavini ali delu vplivajo na spremembe $v$ tem ekosistemu in zaradi izrazite odprtosti in prehodnosti urbanega ekosistema, tudi v sosednjih. Če mesto torej razumemo kot sistem njegovih naravnih in antropogeno preoblikovanih sestavin in njihove soodvisnosti in součinkovanja, lažje prepoznamo tudi njegove nosilne sposobnosti, oziroma v končni fazi še stopnjo ranljivosti urbanega okolja. Holističen pogled na urbani ekosistem nam omogoča še, da ga ne vidimo le kot seštevek posameznih sestavin, ampak kot proizvod njihovega sinergijskega součinkovanja. Ekosistemski pristop je tudi pot k boljšemu razumevanju mestnega metabolizma, ker lahko sledimo snovno-energetskim vnosom in iznosom, pretoku in energetskim pretvorbam in s tem tudi razložimo povečevanje nereda (entropija) in odpadkov v vseh agregatnih stanjih, ki znižujejo kvaliteto urbanega okolja ter povečuje obseg in intenzivnost negativnih pokrajinskih učinkov na mesto in zaledje.

Poseben metodološki izziv pri preučevanju urbanih - najbolj odprtih ekosistemov predstavlja njihovo definiranje oziroma omejevanje. Obravnavamo jih lahko kot 'pogojno zaprt sistem', kjer se izpostavijo razlike med posameznimi deli znotraj mest. Druga raven, kjer se najbolj približamo izvornemu ekosistemskemu pristopu, omogoča obravnavo mesta kot organizma s svojim metabolizmom oziroma snovno-energetskimi vnosi in iznosi, torej kot izrazito odprt sistem, ki součinkuje tudi s sosednjimi. Mesta pa lahko razumemo tudi kot dele regionalnih in globalnih ekosistemov.

Ugotavljamo, da še vedno prevladujejo mesta, ki zgolj prisegajo na trajnostni razvoj, $\mathrm{v}$ praksi pa se celo odmikajo od ekosistemskega ravnovesja in s tem tudi od koncepta samozadostnosti in upoštevanja lastne nosilne sposobnosti. Napake so vidne na gospodarskem in socialnem področju, predvsem pa v poslabševanju kvalitete mestnega in širšega okolja in njegovih sestavin. Jasno je, da alternative trajnostnemu razvoju ni, zato so pri približevanju tem ciljem dobrodošli že majhni koraki. Veliko bo narejenega že s spremenjenimi vzorci obnašanja ter $\mathrm{z}$ večjo ozaveščenostjo. Vse več strokovnjakov razume trajnostni razvoj mest tudi v njihovi optimalni samozadostnosti in postopnem zmanjševanju odvisnosti od produkcije v drugih okoljih.

Aktualna priporočila za kakovostni trajnostni razvoj urbanih ekosistemov še vedno močno izpostavljajo potrebo po prepoznavanju njihove nosilne sposobnosti. Pri načrtovanju uravnoteženega razvoja mest obstaja tudi nekaj univerzalnih kvalitativnih sprememb, s katerimi bi se mesta dolgoročno lahko približala trajnosti in ekosistemskemu ravnovesju in to brez velikih posegov in finančnih vlaganj.

\section{Viri in literatura}

Berry, B. J. L. in sod. 1974: Land use, urban form and environmental quality. The University of Chicago research paper 155. Chicago. 
Boyden, S. 1977: The ecology of a city and its people: the case of Hong Kong. Canberra.

Breheny, M. J. 1992: Sustainable development and urban form. London.

Burdett, R. 2008: The versatility of future cities. Ecotopedia - walk the talk. Medmrežje: http://english.dac.dk/db/filarkiv/10285/FINAL_AVIS_low.pdf(10.6.2009).

Dekleva, J. 1998: Pregled instrumentov prostorske regulacije. Ljubljana.

Douglas, I. 1983: The urban environment. London.

Drozg, V. 1995: Morfologija vaških naselij v Sloveniji. Geographica Slovenica 27. Ljubljana. Environmental policies for cities in the 1990s. OECD. Pariz 1990.

Gehl, J. 2008: Making healthy cities. Ecotopedia - walk the talk. Medmrežje: http://english. dac.dk/db/filarkiv/10285/FINAL_AVIS_low.pdf(10.6.2009).

Girardet, H. 2008: The self-sufficient city. Ecotopedia - walk the talk. Medmrežje: http:// english.dac.dk/db/filarkiv/10285/FINAL_AVIS_low.pdf(10.6.2009).

Havlick, S. W. 1974: The urban organism. New York.

Keuc, A. 2005: Preprečevanje in zmanjševanje odpadkov v Sloveniji. Ljubljana.

Nijkamp, P., Perrels, A. 1994: Urban sustainability as a new paradigm. V: Sustainable cities in Europe. London.

Plut, D. 2006: Mesta in sonaravni razvoj. Geografske razsežnosti in dileme urbanega sonaravnega razvoja. Razprave Filozofske fakultete. Ljubljana.

Plut, D. 2007: Okoljska analiza in presoja prostorskega razvoja Mestne občine Ljubljana v obdobju 1990-2015. Ljubljana.

Pogačnik, A. 1999: Urbanistično planiranje. Ljubljana.

Southworth, B. 2008: Creating compact communities. Ecotopedia-walk the talk. Medmrežje: http://english.dac.dk/db/filarkiv/10285/FINAL_AVIS_low.pdf(10.6.2009).

Špes, M. 1998: Degradacija kot dejavnik diferenciacije urbane pokrajine. Geographica Slovenica 30. Ljubljana.

UNU/IAS Report 2003a: Urban ecosystem analysis - identifying tools and methods. Tokyo. Medmrežje: http://www.ias.unu.edu/binaries/UNUIAS_UrbanReport2.pdf(10.6.2009).

UNU/IAS Report 2003b: Defining an ecosystem approach to urban management and policy development. Tokyo. Medmrežje: http://www.ias.unu.edu/binaries/UNUIAS_ UrbanReport1.pdf (10.6.2009).

Vink, A. P. A. 1983: Landscape ecology and land use. London.

Wackernagel, M., Rees, W. 1996: Our ecological footprint. Reducing human impact on the Earth. Global Island.

Wackernagel, M. 2008: Wrestling the footprint. Ecotopedia - walk the talk. Medmrežje: http://english.dac.dk/db/filarkiv/10285/FINAL_AVIS_low.pdf(10.6.2009).

\section{A TOWN AS AN ECOSYSTEM}

\section{Summary}

In the comprehension of towns with the aim to plan their sustainable development, the ecosystem approach has many comparative advantages as regards the detailed investigations of individual components or activities of an urban ecosystem. The comprehension of a town 
as an ecosystem also makes possible to search for the balance between all the elements of urban life, as well as between the inputs and outputs, or their evaluation as to the carrying capacities of the urban environment. Sustainable development - which is essentially an evolutionary process of constant search for the balance between the carrying capacity of an ecosystem and the changes which in long term result in social, economic and technological developments - requires the knowledge and understanding of all the ecosystem components and in particular the net of their inter-connectedness. Changes in an individual component or part of it bring about changes in the entire ecosystem, and due to the explicit openness and transition feature of an urban ecosystem, also in the neighbouring ones. Thus, if a town is understood as a system of its natural and anthropogenically transformed components, and their interdependence and co-functioning, it is also easier to identify its carrying capacities and, in the final stage, the degree of vulnerability of the urban environment. A holistic view of the urban ecosystem also makes possible that it is not merely seen as a sum total of individual components, but as a product of their synergic cooperation. The ecosystem approach further stimulates a better comprehension of the town's metabolism, since it is possible to follow up the material-energy inputs and outputs, the flow and transformations of energy and, consequently, to account for the increase in disorder (entropy) and wastes in all aggregate states, which decrease the quality of urban environment and increase the extent and intensity of negative landscape impacts on the urban hinterland.

A special methodological challenge in the study of urban ecosystems, the most opened ones, is further represented by their definition and demarcation. They can be studied as a 'conditionally closed system', in which differences between individual parts of the towns are pointed up. Another level which brings us closest to the original ecosystem approach enables dealing with a town as an organism with its own metabolism, or material-energy inputs and outputs, which means, as an explicitly open system which co-functions also with the adjacent ones. However, towns can also be comprehended as parts of regional and global ecosystems.

Established has been the continuous prevalence of towns which only pretend to follow sustainable development while in fact their practice even diverts from ecosystem balance and thus from the concept of self-sufficiency and taking account of their own carrying capacity. The faults are evident both in the field of economy and social affairs, and mainly in the impairment of the quality of town- and wider environments and their components. However, it is clear that there is no alternative to sustainable development, so that even little steps are welcome in order to get closer to this objective. A lot could already be done with the changed patterns of behaviour and the growth of awareness. An ever greater number of experts understand sustainable development of towns also as their optimum self-sufficiency and a gradual reduction of their dependence on production in other environments.

Current recommendations for qualitative sustainable development of urban ecosystems keep emphasizing strongly the need for recognizing their carrying capacities. Furthermore, some most renowned experts in the field of planning balanced development of towns have concluded that towns will approach sustainability faster, if they succeeded in providing:

- compactness - condensation of the town, not tending to spatial expansion and growth but granting mixed land use, without separating diverse fields of human activity; 
- well organized transport, and prevailing use of renewable energy resources in public transportation and its high quality and accessibility, and above all, safety for pedestrians and cyclists;

- stimulation to building energy-saving- and local-environment-friendly buildings by using building materials and techniques that are adjusted to the natural conditions and also to the anticipated climate changes;

- transition to renewable energy resources;

- preserving and creating green areas and natural aeration corridors in the form of ecotopes which significantly contribute to the quality of urban ecosystem;

- advancing to the natural material-energy cycle - the cyclic metabolism of the town where wastes are also integrated into the production of biomass;

- increased self-supply of the town - the carrying capacity of an urban ecosystem is also assessed by the percentage of the needs and requirements for life and functioning of all subsystems that can be secured by the town's potential;

- coordinated and balanced functioning of all subsystems within the urban ecosystem can only result from well considered planning, so that the subsystems supplement one another to avoid spatial conflicts and domination tendency.

(Translated by Branka Klemenc) 